\title{
THE HISTORY OF THE NAMES HELLAS, HELLENES.
}

IT has sometimes occurred that a specious explanation of a fact, or a specious amendment of an error, has established itself so firmly in the court of history, that no one dreamed of disputing its claim to be unquestionably correct. At last, by accident, a doubt arises in some one's mind; and, after enjoying a long protracted success, the universally received solution, when its antecedents are investigated and its implications realized, turns out to be wholly 'impossible.' It may be easily shown, I think, that such is the case with the traditional explanation of the extension of the names Hellas and Hellen to the wide signification which they bore since the seventh century B.c. This explanation has had the inestimable advantage of resting on the authority of Thucydides; ${ }^{1}$ and it belongs to that class of explanations which merely require to be stated in order to recommend themselves, and which the human mind is accordingly inclined to accept unreflectingly. It has come to be regarded as a commonplace historical fact; yet it is noteworthy that in some recent histories of Greece ${ }^{2}$ it is simply stated that the Greeks adopted Hellenes as a common name, without any suggestion of an answer to the obvious question why that name was chosen rather than another. The authors apparently felt some difficulty in accepting the exposition of Thucydides. E. Meyer seems to have realized the difficulty more fully, ${ }^{3}$ and some remarks which he offers on the point will call for notice. In this paper I propose to exhibit the difficulties which render the received view untenable, and to put forward another explanation in its stead. The problem is: How came "E $\mathrm{E} \lambda \boldsymbol{\lambda}$ ves to be the common name by which the Greek peoples distinguished themselves as a race from those whom they called 'barbarians'? How came Hellas to be the name of the land, which we in western Europe call Greece? The solution involves the discussion of another problem, -a problem of exegesis which occurs in the Telemachia and has not received sufficient attention. With this subordinate question it will be convenient to begin.

The description of the leavetaking of Telemachus from his Spartan host, king Menelaus, at the beginning of the 15th Book of the Odyssey is familiar to every one who is likely to read these pages. But it will be well

i. 3.

2 Busolt, Gr. Gesch. vol. i. 2nd ed. p. 197 ;
Beloch, Gr. Gesch. vol. i. p. 272.

3 Gesch. des Alterthums, ii. p. 534. 
briefly to recapitulate the circumstances. Telemachus visited Sparta for the purpose of learning tidings about his father. He sailed from Ithaca to Pylos, and he was driven from Pylos to Sparta, by way of Pherae, ${ }^{4}$ by Nestor's son Pisistratus. He stays a night at Sparta, is invited to stay longer, and might have accepted the invitation, if he had been left to himself; but he receives an urgent warning from Athena, before dawn, not to tarry longer, ${ }^{5}$ and accordingly he accosts Menelaus at break of day, asking permission to return home at once.

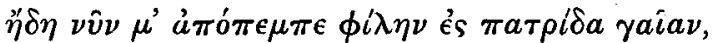

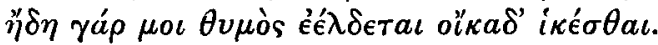

By the emphatic position of $\not \delta \delta$, at the beginning of both verses, the speaker shows how great is his haste. 'Even now send me back to my country ; for my soul yearneth to go home this very hour.' Menelaus assents, with courteous phrases, to his guest's wish. 'Telemachus,' he says, 'I will not detain you, since you desire to return. A host who keepeth a guest against his will is, to my thought, as bad as he that urgeth a guest forth who would fain abide. But at least wait till I bestow gifts upon you.'

So far, well ; indeed, nothing could be better. But what follows?

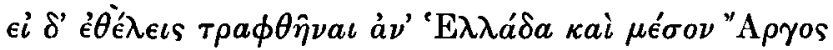

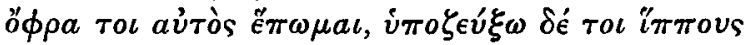

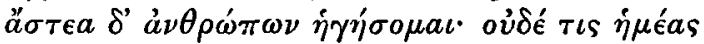

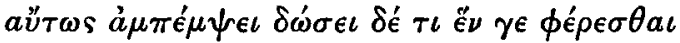

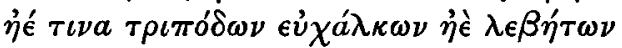

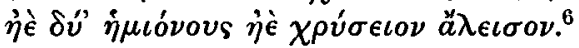

'But if you will wend through Hellas and mid Argos, I myself escorting you, well and good, ${ }^{7}$ - I will yoke the horses and conduct you from city to city. None will send us home empty, but all will give us something, a tripod, a cauldron, a gold cup, or a pair of mules.' 'Nay, answered Telemachus, 'I prefer to return forthwith, for I left none at home to guard my chattels.'

\footnotetext{
4 On the rout of Telemachus and Pisistratus see the recent investigations of $\mathrm{M}$. Pernice, Nittheilungen 1894.

5 $\circ 9-42$; cp. 10

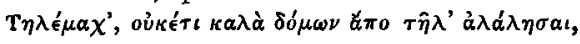
$\kappa, \tau, \lambda$.

and 14,15

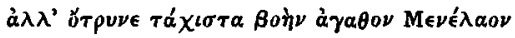

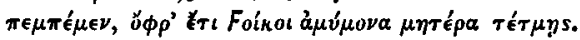

6 v. $80 s q q$.

7 Sé of course marks the apodosis (so schol. $h, \pi \lambda \epsilon o \nu \alpha ́(\epsilon l)$. It is not scientific to regard an

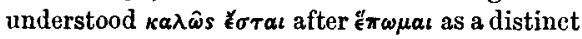
way of construing (Hayman); for an understood $\kappa \alpha \lambda \omega s$ lorat is simply the explanation of apodotic $\delta$ ': 'well-but, in that case,' \&c.-
}

Aristarchus gave another construction which is clearly wrong. He punctuated after $2 \theta \epsilon \lambda \in i s$ and explained $\tau \rho \alpha \phi \theta \hat{\eta} \nu \alpha$ as imperative. Mr. Hayman ascribes this to a perception of a certain want of connexion in $\nu \phi \rho a$, and remarks that the remedy is 'at some expense of propriety in the sense.' The óppa clause will demand some attention at a later stage of our discussion. In the paraphrase which I have given above, I have abstained from insisting on its precise meaning. In $\Phi 487$ ci $\delta^{\prime} e^{2} \theta$ é $\lambda \in \iota s .$.

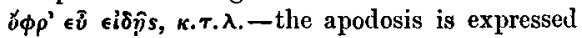
by the action which immediately follows $\eta \rho \alpha$

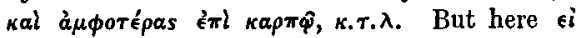
é $\theta$ é $\lambda \in t s$ is 'since you wish.' 
It may seem astonishing to find Menelaus first readily acceding to the clearly expressed desire of his guest, and then, in the same breath, making a proposal, the acceptance of which, however we interpret its terms, would have implied for Telemachus a longer absence from Ithaca than another day or another two days spent at Sparta. Our astonishment however may be provisionally stilled by the reflection that the proposal of Menelaus offered inducements which might seem to him to justify a delay of several days, though a delay of even one day at Sparta, without such inducements, could not be fairly recommended to a man who professed to be in haste. The inducements were the opportunity of seeing something of the world-' the cities of men'-, and the rich presents which were to be collected on the journey. ${ }^{8}$ The one condition that such a proposal could, under the circumstances, be entertained at all, was evidently that the delay which it involved should not be too long. And it was meant seriously. The king does not say: 'If you were not so pressed for time, I should have invited you to come with me on a tour through Hellas and mid Argos'; but, 'if you wish to go, I will come with you.' ${ }^{9}$ It was a polite offer, and Menelaus may have felt that it would be more probably declined than accepted; but it was clearly an offer whose acceptance was by no means out of the question. But what. exactly was this proposal? What places did Menelaus propose to visit?

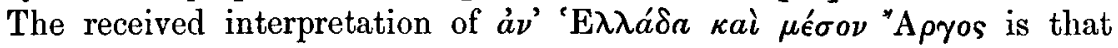

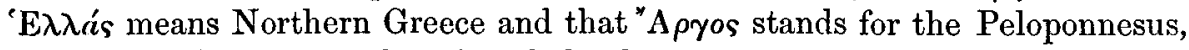
a part typifying all; so that the whole phrase means 'Greece'-Hellas in the later sense of the name. $\mu \epsilon^{\prime} \sigma o \nu$ is taken to designate Argos as in the middle or heart of the Peloponnesus. ${ }^{10}$ Before discussing the validity of this interpretation, I would make three preliminary observations, in respect to (1) the origin of the interpretation, (2) the meaning of "A $A$ yos, and (3) the force of

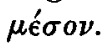

(1). The received view has certainly the merit of antiquity, for it is as old as the final redaction of the Odyssey. The composer of the first Book of that epic was also, as Wilamowitz-Möllendorff has convincingly proved, ${ }^{11}$ the arranger of the whole poem in its present form. This poet (who did not live earlier than the middle of the seventh century) borrowed the phrase under

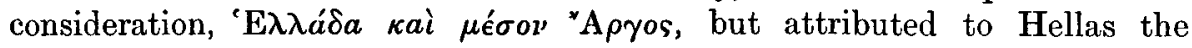
wide significance with which he was himself familiar. He describes the fame

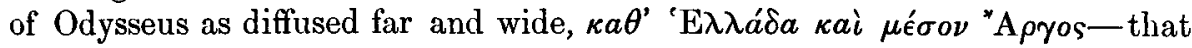
is, throughout the whole of Greece; ${ }^{12}$ the phrase being of the same nature as

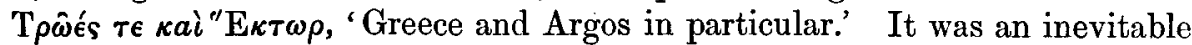
consequence that the obvious meaning of the expression in this later passage

\footnotetext{
$8 \mathrm{Mr}$. Hayman assigns as the motive the opportunities which Telemachus would have, on such a tour, of prosecuting inquiries about his father. But the poet does not hint at this infucement.

9 It was clearly intended by Menelaus that Pisistratus should return straight to Pylos with Nestor's chariot. This is rightly noted by

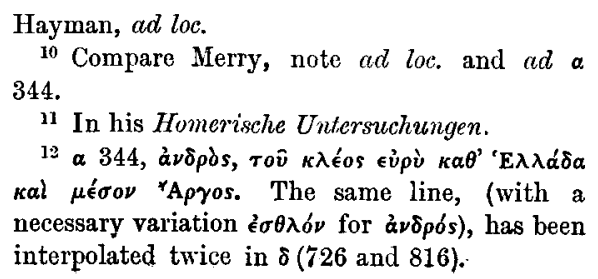

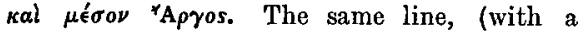

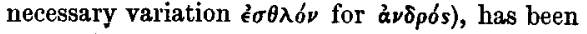
interpolated twice in $\delta$ ( 726 and 816$)$. 
should be transferred to the original, and far older, passage, which was incorporated in the fifteenth Book. Only, modern interpreters have introduced a refinement in the explanation of the phrase. They take Hellas to mean Northern Greece-though there is no reason to suppose that such a sense was attached to it by the author of Book i.; and they are consequently obliged to explain "A $\rho$ ros as typical, not literal, in order that the sum 'E $\lambda \lambda \dot{a}$ s +"A $\rho$ ros may be equated to Greece.

(2). As to the original meaning of "A $\rho$ yos there is of course no doubt. It meant the Argive plain, not the city. In all early parts of the epic, it meant one of two plains, either the northern horsefeeding Argos in the land

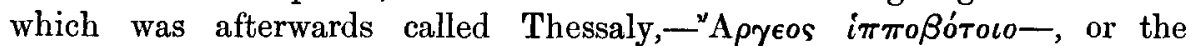
southern Argos of the Peloponnesus. Only in some later passages is it found designating the city which grew up beneath the castle of Larisa.

Can Argos be used as representative of the whole peninsula, of which it was unquestionably a politically important district? The commentators seem hardly to realize that the assumption of such a usage requires some vindication. They might with considerable plausibility adduce a verse of the Iliad, ${ }^{13}$ where it is suggested that Greeks and Trojans should conclude a peace, and that the Greeks should return home

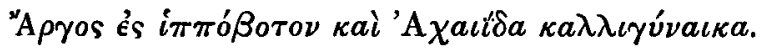

Here, it might be said, Argos represents the Peloponnese, Achaiis represents North Greece, and the whole phrase is simply equivalent to Greece. But if we look a little deeper, we can see that this exegesis is not strictly true. The two most important chieftains on the Greek side in the legend of Troy were Agamemnon and Achilles. Agamemnon commanded the Argives and Achilles the Achaians; hence Argives and Achaians came to be used, representatively, and indifferently, for the Greek host. Thus when it is said 'let them return to Argos and Achaia,' the two most important contingents, the Argives and Achaians, are singled out as representative of the army. The phrase implies the well-known representative usage of the national names, Argive and Achaian, in regard to the host before Troy; but it need not imply any representative force in the corresponding geographical names, Argos and Achaia.

There is another way by which it might be plausibly attempted to elicit the meaning 'Peloponnesus' from Argos. It may be rightly said that Argos, being the most important part of Agamemnon's realm, could naturally and fitly designate the whole of his realm, ${ }^{14}$ and that, as his realm covered a large part

13 Г 75, compare Hentze's note 'der südlichste und nördlichste Landstrich formelhaft für das gesamte Griechenland.' Such geographical abbreviations seem most unlikely.

It is worth while noting that this line may not be due to the author of $\Gamma$, but may have been borrowed of him from a much older epic poem, a true Achilleid, in which-as $i \pi \pi 6 \beta$ Botov shows-it would have referred to the northern Argos which was contiguous to Achaiis,
It has been suggested by a German commentator (Ameis) that the northern Argos is meant in $\Omega 437$, where Hermes, personating a follower

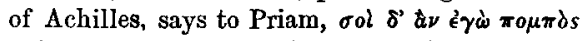

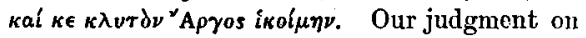
this point will depend on our view of the date of $\Omega$.

14 That "Apros is used in this sense will be shown hereafter. 
of the peninsula, Argos was approximately equivalent to 'Peloponnesus.' It seems to me that such a view might fairly be entertained so far as the name "A pros itself is concerned ${ }^{15}$; but then, if "Apros means the realm of Agamemnon, or practically the Peloponnesus, what is the force of the epithet

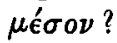

(3) And in any case, as applied to the literal Argos, what is its force? It is obvious that 'A "A Peloponnesus,' is either false or pointless. It is false if $\mu$ é $\sigma o \nu$ be taken strictly, for Argos is not Arcadia; it is pointless if $\mu \epsilon^{\sigma} \sigma o \nu$ be taken loosely, for in this case the epithet would be equally applicable to Sparta or Elis. To translate $\mu \epsilon^{\prime} \sigma o \nu$ as central, with the suggestion that it was a centre of traffic, is little more than to evade the difficulty by a rendering which, with a deceptive appearance of being literal, lays more meaning on the Greek word than it is capable of bearing. The only tenable ${ }^{16}$ explanation is that of $\mathrm{Mr}$. Hayman, who takes $\mu$ é $\sigma o \nu$ as describing the position of Argolis between Lacedaemon and Thessalian Hellas.

It has seemed well to call attention to these subordinate difficulties before approaching the more decisive questions, which we must now consider.

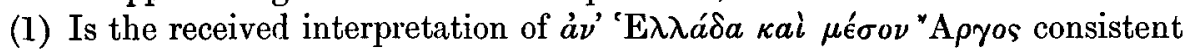
with the context? (2) What grounds have we for ascribing to 'E $\mathrm{A} \lambda \lambda_{a}$ 's the signification 'Northern Greece'?

I. Those who have studied the constitution of the 'Homeric' state on the evidence of the Homeric poems might feel inclined to hold the view that the meaning of the proposal of Menelaus, made in such a very businesslike way, was not to pay visits to foreign princes, but rather to make a progress through dominions which were in some way dependent on himself, and in which he would therefore have a right to exact presents from the lords of the land. Those from whom he expected to receive tripods and mules would be $\beta a \sigma \iota \lambda \hat{\eta} \epsilon s$ standing to him in a like relation to that in which the $\beta a \sigma \iota \lambda \hat{\eta} \epsilon s$ of Ithaca stood to Odysseus, or those of Scheria to Alcinous. And so this passage ${ }^{17}$ would illustrate the prerogatives of Homeric kings-the $\delta \omega \rho$ $\beta a \sigma \iota \lambda \hat{\eta} \epsilon \varsigma$; and it would follow that Menelaus proposed a tour within the dominions of the Atridae.

It must be remembered that the sovranties of the two brothers were conceived as closely united ${ }^{18}$; one is located in Argos, the other in Lace-

\footnotetext{
15 There are however no passages where such a meaning is necessary.

16 Tenable so far as the Greek is concerned, and on the theory that Hellas is either Thessalian Hellas or Northern Greece. It is not, however, the true explanation-as might indeed be suspected from the fact that it does not take into account the same phrase ("Apyei $\mu \in \dot{\sigma} \sigma \boldsymbol{\sigma})$ in $\mathrm{Z} 224$.

$: 7$ Menelaus exacting presents for Telemachus

from the subordinate $\beta \alpha \sigma \iota \lambda \hat{\eta} \in s$ would be exactly like Alcinous ordering the other twelve $\beta \alpha \sigma \iota \lambda \hat{\eta} \in s$ of Scheria to give presents to Odyssens $\theta 386$ $s q q$, ef $\nu 12$. The kings replenished their coffers by impositions on the $\delta \hat{\eta} \mu o s, \quad \nu 14$

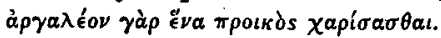

${ }^{18}$ See the 'Map to illustrate the Catalogue of the Ships' in Mr. Monro's edit. of the Iliad, Books i.-xii., where Lacedaemon (including western Messenia) and Argos are marked as one
} 
daemon; but they appear as conjoint rulers, though the exact constitutional relation between them is not further defined than by the ascription of a sort of precedence and primacy to Agamemnon. On the death of Agamemnon, which had already taken place, ${ }^{19}$ while Orestes succeeded his father in the Argive plain, the precedence and primacy in the realm of the Atridae would naturally pass to Menelaus. The extent of this realm is defined in the Catalogue; only, we must restore to the Atridae the kingdom which the author of the Catalogue has carved off for Diomede, including Argos, Tiryns, Troezen, Epidaurus, \&c., ${ }^{20}$ and we must add part of the land to the west of IIt. Taygetus. ${ }^{21}$ Using later geographical terms, the realm of the Atridae accordingly consisted of: eastern Messenia, Laconia, Argolis, with Corinth and Sicyon, Achaea. The parts of the Peloponnesus which it did not include were: Arcadia, western Messenia or Pylos, ${ }^{22}$ Triphylia and Elis. The Atridae had no sovranty in Northern Greece; and therefore, if the interpretation of 'E $\mathrm{\lambda} \lambda a^{\prime}$ s as Northern Greece in the passage before us be correct, we cannot accept what otherwise we might consider likely to be the true view of the nature of the tour proposed by Menelaus.

These considerations, though in themselves quite indecisive, may at least prepare us to approach the passage from a new point of view. Let us now see how far the context may help us to decide.

dominion. But it excludes by a red line Corinth, Sicyon, and the cities of the north coast (Pellene, Aigion, \&c.), so that this map might correspond to an older state of things, which the writer of the Catalogue indicates by

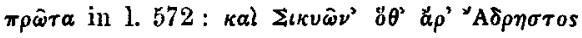

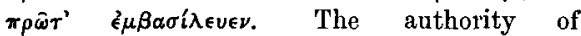
$\Lambda$ gamemnon in the south is marked by his proposal in ix. 149 to give seven Messenian fortresses to Achilles. The common or joint rule of the Atridae is also implied very clearly in the Catalogue. The poet assumes that his heroes would expect to find Agamemnon and Menelaus commanding joint forces, and therefore deems it necessary to state expressly that the Lacedaemonians were mustered separately : 1. $585 \grave{a} \pi \alpha \dot{\tau} \tau \rho \theta \epsilon \delta \dot{\epsilon} \theta \omega \rho \eta \sigma \sigma o \nu \tau o$. The association of Menelaus and Helen with Argos is indicated

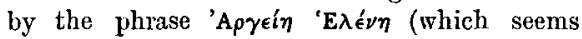
prior to the connexion with Sparta), and possibly the mention of "Apros in $\delta 562$.

$19 \delta 534$. The death of Aegisthus and accession of Orestes have been described in $\gamma$ 304 sqq., and are implied in $\delta 546$.

20 This imnovation was rendered possible by the circumstance that in the older epic the town of Argos did not occur; it was therefore open for Diomede to occupy. In $\gamma 1808 \tau^{\prime} \dot{\epsilon}^{\prime} \nu$

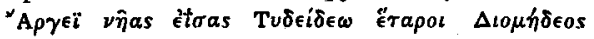

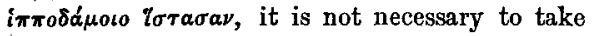
"Apret of the town; but in any case Diomede must be conceived as a $\beta \alpha \sigma \iota \lambda \in \dot{\nu} s$ within the dominion of the Atridae. In $\gamma 260$ (in a con. text which is certainly not an original part of the Telemachy) our texts have-

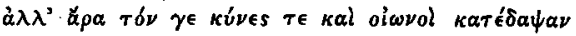

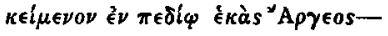

a description of what would have happened to $\Lambda$ egisthus if Menelaus had been at home. "Apreas is nonsense; $(a)$ it cannot mean the land, for ex hypothesi both Menelaus and Aegisthus would have been in the land ; $(b)$ it cannot mean the town, for Mycenae, not Argos, was in question. The right reading is surely ékàs ă $\sigma \tau \in o s$, the variant; which means that Aegisthus would not have had burial in one of the royal tombs around the acropolis of $\mathrm{My}$ cenae. The reading $A p \gamma \in$ os is an emendation for EKACTEOC, one $\triangle C$ having fallen out and $T \in O C$ being taken for $\Gamma \in O C$. The passage was composed in Ionia at a time when $F$ had fallen out of use.

211149.

22 Pylos in the stricter sense as Nestor's realm. The name had also the wider sense of all the land between $M t$. Taygetus and the Ionian sea; it answered, in fact, to the later Messenia. This use is found I 153, where the strongholds Kardamyle, Pherae, etc., are

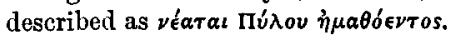


hospitable he is, and what interesting things you will see in the island. Come, what do you say? We then return together here, and you go on straight to Patras.'

What should we think of the sanity or seriousness of a man who made such a speech?

II. We have now to consider what reasons exist, and whether they are valid and sufficient, which force us to attribute to Hellas a signification involving the incongruity we have just noticed in the passage under discussion.

The reason for adopting this interpretation of 'Hellas' is closely connected with the current explanation ${ }^{25}$ of the origin of the use of Hellas as the general name for all Greece. According to this current view, the name Hellas passed through three stages. In the first stage it designated a small district, of which the exact position cannot be identified with any certainty, but which lay in the neighbourhood of Malis and Achaian Phthiotis. In the second stage the name had extended from this little corner to designate the whole of northern Greece as opposed to the Peloponnesus. In its third and final stage it came to include the Peloponnesus as well. The history of the name 'Hellenes' was parallel; but in the last stage it included all men of Greek race wherever their home was.

1. For the first stage ${ }^{26}$ the evidence is clear and remarkable. It is mainly contained in the ninth Book of the Iliad, in the long speech of Phoenix in the episode of the Presbeia. This speech occupies a unique place in the poem; and, notwithstanding the mass of Homeric literature that already exists, a thorough investigation of this ninth Book is still much needed. Phoenix was son of Amyntor, king of Hellas. He relates how he quarrelled with his father, eluded the vigilance of his kinsfolk, and escaping from the

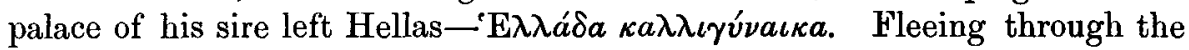

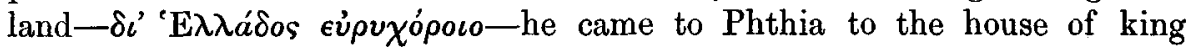
Peleus :

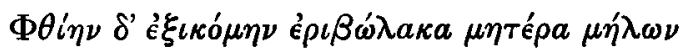 és $\Pi \eta \lambda \hat{\eta} a$ Fáva $\chi \theta^{\prime}$.}

Peleus, receiving him kindly, enriched him and sent him to the eastern borders of Phthia to rule over the Dolopes. ${ }^{27}$

${ }^{9}$ It is hard to find definite and complete statements. I have deduced what I may be permitted to call the current view from a number of statements and implications in the obvious books. As a rule, of course, the proposition is vague: the name 'gradually' spread. For example, in the Strudent's Greece, which in England, I suppose, is the most widely used educational handbook on Greek history, we read (p. 2): 'From this district [in Thessaly] the people, and along with them their name, gradually spread over the whole country south of the Cambunian mountains' (a statement which is otherwise most misleading. I quote from the ed. of 1881).

${ }^{26}$ I am not prepared to go into the derivation of "E $E \lambda \eta \eta \nu$, its possible connexion with

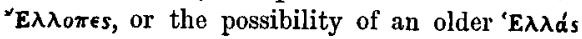
in the region of Dodona. For which see

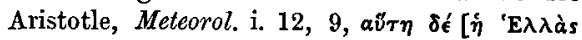

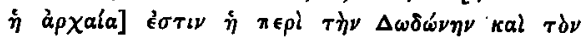

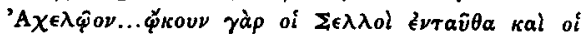

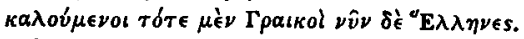

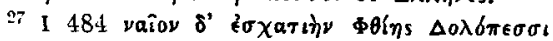

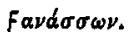


In the same Book of the Iliad, ${ }^{28}$ Achilles, rejecting the conciliatory presents offered by Agamemnon, says: 'There are many Achaean maidens

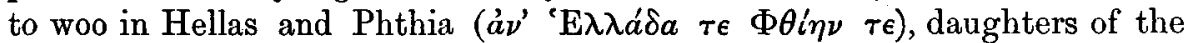
nobles who keep the fortresses.' Again, in the Nekyia ${ }^{29}$ we read of the realm of Peleus in Hellas and Phthia. 'What of Peleus? Has he still honour among the Myrmidons, or do they slight him, in Hellas and Phthia?' And in another passage ${ }^{30}$ we learn the name of one of the chiefs who kept the castles of Hellas. There Glaucus slays Bathycles, son of Chalcon, who, 'dwelling in a house in Hellas, was eminent for wealth among the Myrmidons.'

These passages show that Hellas and Phthia were in close geographical proximity; that Hellas was conceived as part of the realm of Peleus, king of Phthia; and that the Achaeans of Phthia, the Hellenes and the Myrmidons were intimately associated together. It seems to me probable that Hellas corresponded to the south-western part of the later Thessaly. ${ }^{31}$

When we pass from the older parts of the epic to the literature of the seventh century, we are startled to find that the name of the little vassal state of the kings of Phthia has become the name of all Greece; that all Greek-speaking men from Sicily to Cyprus are Hellenes. The earliest instance of this use of the word in a writer whose date we can control is in a fragment of Archilochus: ${ }^{32}$

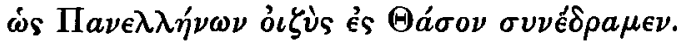

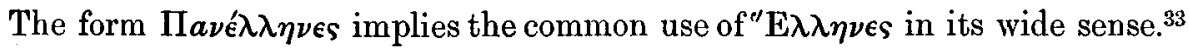
It also occurred in poems of the Hesiodic school; ${ }^{34}$ and the expression

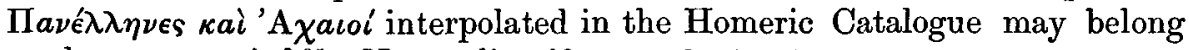
to the same period. ${ }^{35}$ Not earlier, if as early, is the passage in the Works and Days concerning the poetical contest at Chalcis, where we meet the verse : ${ }^{36}$

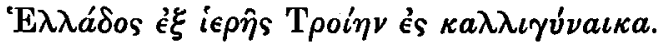

\footnotetext{
28 I 395.

$29 \lambda 495$.

30 1 ก 595 .

31 So Mr. Monro in his note on B. 683 says :

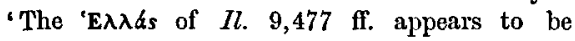
further to the north.' He adds 'outside the kingdom of Peleus.' This raises an interesting point. If we take the narrative of Phoenix by itself, we naturally suppose Hellas to be outside the kingdom of Peleus. But if we take it in connexion with the speech of Achilles, we infer

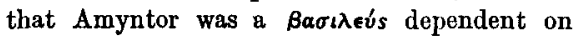
Peleus. To discuss this would take us further into the borders of the Homeric question than is needful for the present purpose.

32 The verse is quoted by Strabo, $370=$ viii. 6, 6. - We may compare the use of Mavaxacol in Homer for 'Axasol in the sense of the whole
}

host.

${ }^{33}$ On the other hand, E. Meyer thinks that

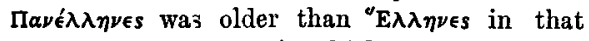
sense. But Ilavaxaıol, which seems a consequence of the wider use of 'Axacol, would point the other way.

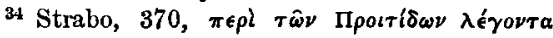

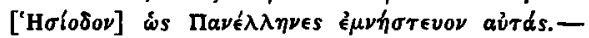

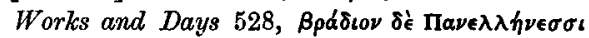
qafivel (in one of the later strata of the poem).

35 B 530. 'It has been supposed, with some reason, that the two lines 529,530 are an interpolation' (Monro).

36 Where Hellas cannot mean anything but Greece. I suspect that the verse may have been borrowed from an old epic, where it would have referred to the original Hellas and the followers of Achilles. 
I have already pointed out that the new use of the name occurs in the Odyssey (see above, p. 219), being used by the bard who put the poem into

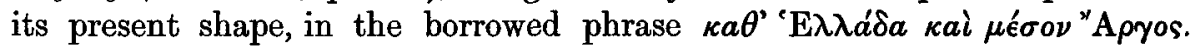
Others, quoted by Strabo, ${ }^{37}$ recognized this signification, and naturally (like the compiler of the Odyssey himself) interpreted the words as used by the poet of the Telemachy in the same way.

The following problem now faces us: How are we to pass from the original meaning which Hellenes bears in the older parts of the epic to the later meaning with which it emerges into view again in the seventh century? An answer to this has been suggested by Thucydides in the critical summary of early Greek history which forms the prelude to his work; and modern historians have reproduced-with or without additions and modificationshis answer. 'Before Hellen, son of Deucalion' he wrote, 'Hellas was not so called. But when Hellen and his sons became powerful in Phthiotis and acquired influence in other Greek states by rendering them help in war,

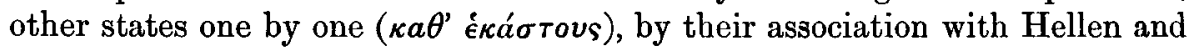
his sons, came to be called Hellenes, but it was not until a long time had elapsed that all came to be called so.' He appeals to the evidence of Homer who confines the name Hellenes to the original Hellenes of Phthiotis. ${ }^{38}$

This paragraph shows very clearly how Thucydides, with all his critical acumen and notwithstanding his sceptical temper, could not get beyond the lines of Greek historical method. Here, he is entirely within the toils of that schematizing of Greek history which was begun in the school of Hesiod. Hellen, the common ancestor of all the Greeks, had no existence, until all the Greeks were called by the name Hellenes. ${ }^{39}$ Hellenes does not presuppose Hellen, but Hellen presupposes Hellenes; of this Thucydides had no conception. And the plausibility of his statement that the Hellenes of Phthia obtained great power and influence among the surrounding states depends on the view that the sons of Hellen were the ancestors of the supposed divisions of the Greek race.

Now Thucydides does not commit himself to the assertion that the name Hellas at any stage designated Northern Greece as opposed to the great Peninsula and the Islands. He only says that it spread gradually,an obvious guess, which might occur to any man in the street and which also, of course, might be true. But if it spread gradually, the Isthmus of Corinth would mark a most natural stage in its progress; and it was this

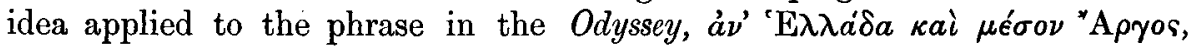
which generated the view that Hellas meant Northern Greece. Other evidence for this supposed second stage of the name there is, so far as I can

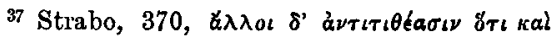

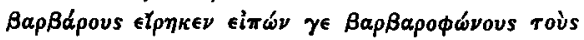

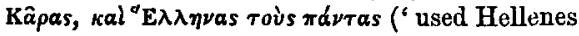
in a universal sense') 'à $\alpha \delta \rho d s$ roṽ $\kappa \lambda \lambda_{\text {éos }} \in \dot{u} \rho \dot{v} \kappa a \theta$ '

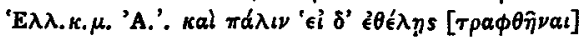
à $\nu$ ' 'E. $\kappa . \mu$. 'A.'

38 Thucydides, i. 3.

39 E. Meyer, Gesch. des Alterthums, ii. 535,
}

has misapprehended this. He derives the Panhellenic force of Hellenes from the mythical position of Hellen as son of Deucalion, the primitive man. But the myth of Hellen was the consequence, not the cause. This must be assumed, unless it can be strictly proved that the genealogy was older than the Hesiodic schonl of the seventh century. 
discover, absolutely none; and we have seen what difficulties are involved in this interpretation of the phrase in the Telemachy.

In accepting the view of a gradual extension of the Hellenic name over North Greece, historians have failed to realize the conditions which such an extension implies. There are two conceivable ways in which the name might have thus spread-conquest and federation. If the Hellenes had reduced under their sway a considerable number of the northern states, or had, as Thucydides suggests, obtained such a preponderating influence as to be practically overlords, we might have no difficulty in acquiescing in the received doctrine. But of such conquest or overlordship there is no trace; and there seems to be no room for it chronologically. If this had been the political situation before the invasion of the Thessaloi, we should expect to find some record of it in the epic; but (apart from the disputed passage in the Odyssey) there is none. And the chief fact to which our records point after the Thessalian invasion is the southward pressure of the Thessalians towards Phocis, a situation which not only ignores, but hardly leaves a place for a large Hellenic realm or sphere of influence.

And a North Greek federation to which the Hellenes as prominent members might have given their name, would be an equally groundless supposition. The North Greek federation of which we know, which had its religious centre at the temple of Demeter at Anthela,-i.e. in the south of Homeric Phthia, the land with which the Homeric Hellenes were so closely linked-this league or amphictiony knows nothing of the Hellenic name. Yet if there were any truth in the common explanation of the history of that name, the Amphictionic league, whose heart was in the neighbourhood of old Hellenic soil, is the institution in which we might expect to find a trace of the supposed prominence of the Hellenes. In the seventh century, as we have seen, the name Panhellenes had come in, but there is not a sign that it had any connexion with the Amphictiony. The sanctuary at Anthela was not a Panhellenion. Thus the only tendency towards a unity of Northern Greece which we can discover in early history namely the religious league which worshipped Demeter in common, was one with which the original Hellenes had nothing to do-and that although original Hellas was near the sacred centre at which the 'dwellers around' assembled.

It seems then that an historical inquirer must look round for some new explanation of the transition from the earliest to the later meaning of Hellas, and also that the student of Homer must seek some new solution of the line in the Telemachia of which we have said so much in the preceding pages. These two problems work into each other.

The chief fact that we can be said to know about the Hellenes of Phthiotis is that in historical times their name had entirely disappeared from the regions between the Spercheus and Peneus. The original Hellas had vanished and left not a track behind. Just the same lot had befallen the Myrmidons; who knew what their ă $\sigma \tau v \pi \epsilon \rho \kappa \lambda v \tau o ́ \nu$, mentioned in the 
Telemachy, ${ }^{40}$ was? That there had once been a Hellas, that there had once been Hellenes in those regions was well known, because Homer was well known; but where exactly Hellas was, none could do more than guess. It was supposed to have extended from old Pharsalus to Phthiotic Thebes. There was also an idea that there had been a town called Hellas-for which Homer certainly furnishes no support; ${ }^{41}$ and the antiquaries of two Thessalian cities set up rival theories as to its location. The Pharsalians said it had stood in the neighbourhood of their city, while Melite put forward another claim. ${ }^{42}$ These facts are of some importance in illustration of the circumstance that no trace of the Hellenic name survived in those regions.

For we surely cannot suppose with Leake that any such trace could remain in ' $\mathrm{E} \lambda \lambda \lambda^{\prime} \delta \delta a$, which is stated to be a modern name for the river Spercheos. ${ }^{43}$ I may observe that in the lower part of the Malian plain this name is now quite unknown. I took pains to inquire, at Lamia and in its neighbourhood, of a considerable number of persons of different classes, by what name the river was known. All, of course, replied at first: $\Sigma \pi \epsilon \rho \chi \epsilon \iota$ 's. When I pressed them for a 'Romaic' name, they all said: 'A $\lambda \epsilon \mu a \dot{\nu} \nu a$. When I then asked them whether they had ever heard it called 'E $\mathrm{A} \lambda a^{\prime} \delta a$, the answer was always negative. Perhaps however this name may be in use higher up the river. In any case, it was used in Leake's day. ${ }^{44}$ But it cannot have been used in classical times, for it would certainly have been adduced to locate Homeric Hellas. We may conjecture that its origin had something to do with the medieval Theme of Hellas, which corresponded to NorthEastern Greece.

The Hellenes then, who according to Thucydides gained such great power in the north, mysteriously disappeared. The question is, What became of them? To answer this question, I must invite attention to the Achaeans of Phthia, with whom they are so closely associated in our Homeric evidence.

Of that series of migrations which changed the geography of Northern

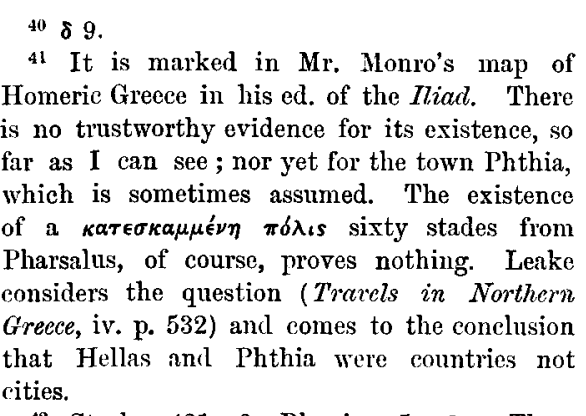

42 Strabo $431-2=$ Bk. ix. 5, 6. Three questions are mentioned here as matters of controversy: (1) whether Phthia, Hellas and Achaia are the same or not; (2) whether Hellas and Phthia are countries or cities in Homer; (3) whether if Hellas was a city it is to be identified with a ruin sixty stades from Pharsalus, or with another ten stades from Melite.

${ }^{43}$ See Leake's Travels in Northern Greece, vol. iv. p. 532: "The kingdom of Achilles, or' rather of Peleus, comprehended at its southern extremity not only Trachinia but also a portion of what was afterwards Locris. To this was added all the fertile valley of the Spercheios, which river still bears the name Elladha or that applied by Homer to the country itself, together with the hilly country northwarl of that river as far as the plains of Thessaliotis.' Thus Leake placed Hellas south of Phthia.

44 See foregoing note, and Leake, vol. ii. c. $x$. passim. Lolling, in Baedeker's Greece, mentions the name Helláda. Did he hear it, of did he take it from Leake? 
Greece and still more of the Peloponnesus, and which are generally described under the improper title of the Dorian Invasion, we have no historical record, and we can only infer what happened from the results. Some of these results appear vividly marked upon the map; for example, the splitting asunder of Locris into three separate lands. ${ }^{45}$ Another prominent geographical fact from which we are entitled to draw a conclusion is the appearance of Achaeans on the northern coast of the Peloponnesus. This coast-land is not called Achaea in the Homeric poems, but at the threshold of history we find Achaeans settled there. The origin of these Achaeans was obscured by the false practice of applying the name 'Achaean' to the pre-Dorian inhabitants of the Peloponnesus, and this practice was due to the Homeric use of the name as a general designation of the Greeks fighting before Troy. 'A $\chi a \iota \iota^{\prime}$ and 'A $\rho$ yei $\iota \iota$ were regarded as interchangeable, and confounded.

The view that the people of Agamemnon, that is, the inhabitants of the western Peloponnesus in the Mycenaean age, were 'Achaeans,' is however still so widely accepted that the evidence which might be adduced to uphold it must be more closely examined. (1) This view is always assumed in proving that the Cypriote Greeks were colonizers from the Peloponnesus. As it is, on other grounds, certain that Cyprus was colonized by the 'pre-Dorian' inhabitants of the Peloponnesus, the same scraps of evidence might be applied, conversely, to demonstrate that those inhabitants were Achaeans. The scraps are : (a) the existence of a 'beach of Achaeans,'

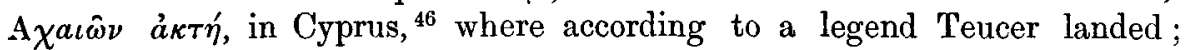

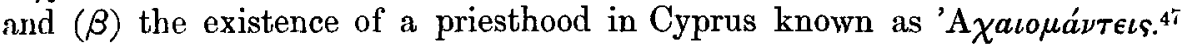
Now in judging of these facts we must remember that we have no reason whatever for assuming that Cyprus, though certainly colonized mainly, was colonized only, from the Peloponnesus. There is no cause why we should not accept evidence proving that there were isolated settlements derived from other Greek lands. Therefore the double occurrence of the Achaean name in Cyprus, or its single occurrence in Rhodes, ${ }^{48}$ does not involve Peloponnesian Achaeans. The Greek colonization of Crete may be properly compared. In that island we find settlements from Thessaly as well as from the Peloponnesus.

It appears to me that the only scientific interpretation of these pieces of evidence bearing on the Achaean name, as well as another more striking and, it must be owned, more doubtful piece of evidence still to be mentioned, is in reference to a great Achaean realm in Thessaly, which is presumed by the epic (the realm of Peleus), and of which the historic Achaeans of Phthiotis were a survival. To it we must refer the Aqaivascha who in the

45 It is worthy of attention that the Ozolian Locrians do not appear in Homer. We may infer that they were unknown to the earlier, and ignored by the later, poets. Yet Phocis appears in the Homeric map, and restern
Locris was a consequence of Phocis. ${ }^{46}$ Strabo $682=$ Bk, xiv, 6,3 .

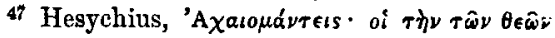

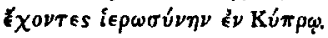

${ }^{48}$ Athenaeus viii. 360 . 
thirteenth century ${ }^{49}$ landed on the Cyrenaic coast and invaded the Delta, along with the Turscha, the Schardana, and others. ${ }^{50}$ The sea-power of this Achaean kingdom was truthfully preserved in the legend which made the Argo sail from Iolcus.

(2). Another argument for Peloponnesian Achaeans may be found

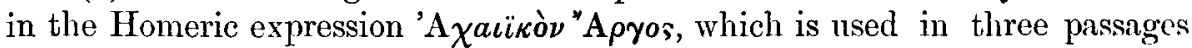
of the southern Argos. But not one of these passages carries any weight, for they are all too late to prove, by themselves, that Achaeans inhabited Argos in the 'Mycenaean' age. The phrase, possibly, was used in older poems, in a strict sense, of the northern Argos, and later poets, finding it ready to hand, applied it otherwise. In any case, the passages where wo meet it represent a period considerably later than the Dorian invasion, when the Achaean name had come to be associated with southern Argos. They occur in the Presbeia (in Agamemnon's proposal of overtures to Achilles) $;^{51}$ in a digression (which is clearly a later insertion) in the nincteenth book of the Iliad; ${ }^{52}$ and in the Telemachy in the conversation between Telemachus and Nestor respecting the murder of Agamemnon. ${ }^{53}$

To return from the false to the true Achaeans of the Peloponnesus, I submit that the natural inference from the geographical fact of the two Achaeas is that the Achaeans of Phthia were among the newcomers who invaded and took possession of the Peloponnesus. The connexion of Peloponnesian with Phthiotic Achaea is a conclusion as legitimate and certain as the connexion of Asiatic Doris with the Doris of Mt. Oeta. The dialects of both countries be-

49 After the death of Ramses ii. (1280 B.C.) in the 5 th year of Memptah. The identification of Aqaiwascha with 'Axatoí seems probable; at least, there is nothing against it, since it has been established that the words of the Egyptian inscription imply not that they were circumcised but the reverse. See W. Max Müller, Asien und Europa, p. 357, 371 .

50 Assuming Aqaiwascha='A Xacol, we neel not suppose that the Achaeans were the ouly Greeks among the invalers. There may have been 'Mycenaeans' too. The Egyptians would naturally choose the name of one Greek people to designate all.

In the second and greater invasion, about three-quarters of a century later, the name Aqqaiwascha does not occur, but Danaunn. appears. This is supposed to represent $\Delta a \nu a o i$. The equation is as probable, intrinsically, as the other; but we do not accept it so easily, because we know more about the Achaeans than about the Danai. savao is one of the most closely locked secrets of early Greece. It is associated only with Argolis and Egypt. If we remember that 'Apreio is not properly a national name, but merely 'the people who lived in 'Apros,' we may feel strongly inelined to believe that $\Delta a \nu a$ f $^{\prime}$ really was the proper name of the Argive portion of Agamemnon's subjects.

One of the clearest points about the history of epic poetry is that in the older $\check{m} \pi \eta$ Thessalian legend was the foundation, and that the prominence of Peloponnesian Argos was later. This order would corresponel to prominence of the Aqaivasehe in the earlier, and that: of Dananne in the later, invasion of Lower Egypt.

61 I 141 (repeated 283).

52 T 115 . (The insertion runs from 1,90 to 136.)

$53 \gamma 251$

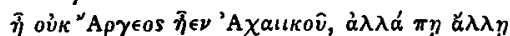

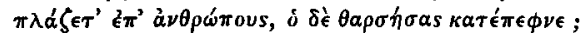
It seems very doubtful whether this account of Agamemnon's death is an original part of the Telemachy. The story is told again (in the month of Proteus) by Menelaus to Telemachus ( 5519 sqq.). In 251 the use of the genitive seems quite impossible. The words ought to mean 'was he not of, did he not belong to, Achaean Argos? was it not his home?' anl the parallel passages cited would only support this meaning. But the sense required by the context is 'was he not, at that time, in Achaean Argos?' 
longed to the same group sometimes called the 'North-western'-the old name was 'Doric'-though the meagre remains of the Phthiotic speech do not allow us to compare the details. ${ }^{54}$ And we have a nota canse to explain the migration, namely the appearance of the Thessalian invaders in the plain of the Peneus. The pressure of the Thessalians will account in the most natural way for the southward movement of a part of the Achaean people. The remnant who stayed behind in Phthia were soon to be reduced to dependence by the new lords who gave their name to 'Thessaly.'

Now, my lypothesis is that the migration of the Achaeans-which secms as certain as any other fact that can be reached by inference concerning the early wanderings of the peoples of Northern Greece-included also a migration of the Hellenes who were so closely associated with them. If the Hellenes abandoned their country to the Thessalians and went forth with their Achaean neighbours to seek a new home in the south, the disappearance of the Hellenic name from its original home is completely explained. If we had nothing more to go on, this conjecture might be reasonably entertained, but we have some confirmatory evidence.

This is furnished by the passage in the Telemachy which has engaged our attention and of which we now hold a satisfactory solution. The Hellenes have moved southward and settled in the north of the Peloponnesus with their Achaean fellows. Here is the new Hellas. Aegion and Pellene, broad Helice, Hyperesia and steep Gonoessa, ${ }^{55}$ all the cities of that coast are Achaean or Hellenic towns. According to the Homeric conception this coast belonged to the realm of Agamemnon. So we must infer from the Catalogue where some of the towns are enumerated and the Airca $\lambda_{\text {ós }}$ is mentioned. None of these cities however is mentioned elsewhere in the Iliad or Odyssey, and therefore it may justly be argued that there is no clear proof that in the older epic the kingdom of Agamemnon had such a large extent. And the author of the Catalogue himself suggests in the case of Sicyon that its connexion with Argos was later. May not the idea of a connexion of the Achaean cities with Argos have been later also? This is quite possible; but for my purpose it is of no consequence. The Catalogue shows that at a later period of the epic, to which the Telemachy also belongs, the north coast of the Peloponnesus was deemed part of Agamemnon's realm. Now before the eighth century, this northern coast of Peloponnesus had become a land of Hellenes, and the author of the Telemachy, composing his poem about that time, might therefore speak of it as Hellas. This is the Hellas meant in the expression a' $\nu^{\prime}$ 'E $\lambda \lambda a{ }^{\prime} \delta a \kappa a i$ $\mu \in ́ \sigma o \nu " A p \gamma o s$.

54 The inseriptions (edited by Fick, in Collitz, Sommlung ii. 1. 34-46) conc from Lamia, Melitaia, Thammakoi, Pteleon, $\Lambda \mathrm{los}$, Thelac, and date chicfly from 3rd and 2nd centuries 13.e. It is important to remember that the Achaean dialect did not approximate to the sroup in which we include the Thessalian and the Aeolic. The Achatean heroes of the
Aeolian epic did not speak $A$ eolic or anything like it, any more than the Pelopomnesian. And yet the Aclaeans were aljacent to men who spoke that dialcet which was alopted by the Thessali:un invaders, and which has so many points of contact with $\Lambda$ eolie

55 B $573-575$. 
Menelaus says to Telemachus: 'Far be it from me to delay you. But I will at least suggest that there is another, though a longer, route, which you might take to Pylos. Instead of returning, as you came, by Pherae, you might go round the Peloponnesus, through "mid Argos and Hellas" (that is, in later phrase, by Argolis and Achaea). You would see something of the world, and I should be delighted to accompany you myself-Pisistratus, of course, returning as he came. It will indeed delay you some days, but then the cauldrons and tripods which we may count on collecting in our progress may be an inducement to you to change your mind.'

On any theory, the king's proposal is made more for the sake of politeness than with much expectation that the guest will yield; but thus interpreted it is a natural and intelligible proposition. The suggestion to make an expedition into Northern Greece, which lay quite out of the way, was, as we saw, preposterous under the circumstances; whereas the suggestion to reach Pylos by a longer route, within the king's dominion almost entirely, was if not very likely to be accepted at least plausible and free from absurdity.

Again this interpretation does justice-and this is not a matter of indifference-to the actual words in which Menelaus couched his proposal, to the words, namely,

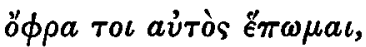

which, as we saw, caused Aristarchus some difficulty. The point of the clause is now seen to be: ' Returning to Pylos as you came, of course you go with Pisistratus. But if you would like me to accompany you (to Pylos), I shall be very glad to do so if you care to take a longer route, and drive round the Peloponnese.' Were the received explanation right, Menelaus would

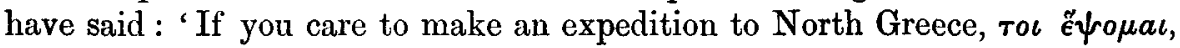

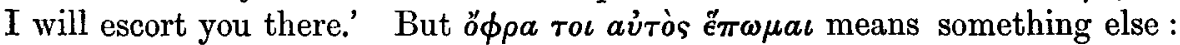
it means ' the proposal I am making implies that $I$ escort you to Pylos instead of Pisistratus.'

Hellas, then, meaning a land within the Atrid realm, the route of Menelans and his guest, if the proposal had been adopted, would have lainuntil they came to the frontier of Elis-in lands where Menelaus, like Alcinous in Scheria, could call upon the princes to present tripods and golden cups to Telemachus.

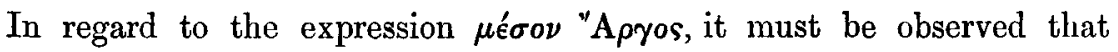
Apros had come, in the later epic at least, to designate not merely the plain in which the fortresses of Mycenae, Larisa, and Tiryns stood, but those lands in the east of the Peloponnesus over which Agamemnon's sway extended. This may be proved from the following passages. (a) "A $\rho$ os included Laconia, for it is said of Menelaus ${ }^{56}$ that he is not destined

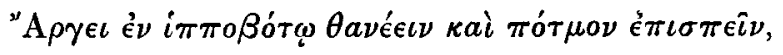


and Menelaus says that he would be ready to transport Odysseus from Ithaca and give him a new home in Argos, 57

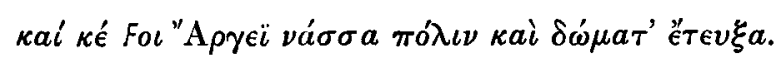

(b) "A pros included Corinth, which, like Mycenae, is said to be ${ }^{58}$

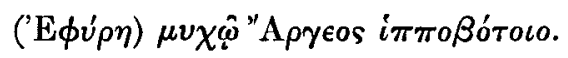

(c) The epithet all in the well-known verse ${ }^{59}$ which sums up the kingdom of Agamemnon

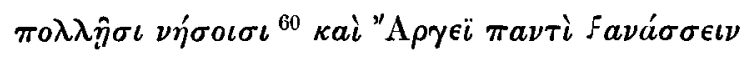

implies such an extended use of the name. On the other hand we have no direct proof that the north coast of the Peloponnese was included in this connotation of the name, and our passage would rather-though not necessarily-imply that it was not. It may also be observed that very late epic poets, such as the author of the last book of the Odyssey, used "Apros in a wide indefinite sense, for 'Greece,' 'home'; for instance, the shade of Agamemnon addresses the shade of Achilles thus : ${ }^{61}$

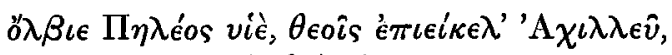

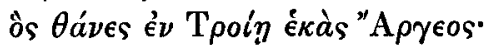

where we may be quite sure that the northern or Pelasgic Argos is not meant.

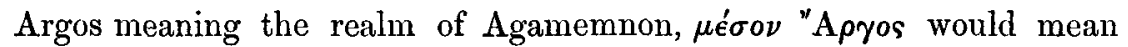
' the middle part of the realm,' and would then be a most appropriate phrase to distinguish the Argive plain, Argos in its original and narrower sense, from Argos in its wider sense. This explanation suits the other Homeric passage in which the expression occurs. In the Iliad, Diomede describes himself as being "A $\rho \gamma \epsilon \ddot{i} \mu \epsilon \sigma \sigma \omega,{ }^{62}$ and his home was in the Argive plain.

The received interpretation has the merit of being received, and those

$57 \delta 174$.

5y z. 152. Some lines below (158) the phrase

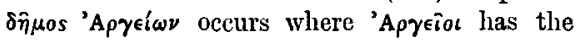
limited sense.

5y B 108-clearly inconsistent with the view suggested by the Catalogue that Diomede had a kingdom independent of Agamemonon.

60 It seems to me probable that the "many islands' incluted, not only the strictly $\mathrm{Argolic}$ -Calauria, Hydra, Spetza-, but Megina and Salamis. Aegina appears as part of Diomede's kingdom in the Catalogue (562), but the indepentence of Diomede is nowhere implied except in this passage, which is clearly 'tendenziüs.' Salamis was, possibly rnled by the Iords of the Palace (Megara), who were probably included, as well as Corinth, in the Iycenaeau realm. It is hard to see any serious objection to the view that Salamis (which may have got its name from pre-Greek, Carian settlers ; cp. Salma-cis) did, as the legend says, take part in the colonization of Cyprus and give its name to a town there. This would not imply that the settlement consisted entirely, or even mainly, of Salaminians.

61 The expression might, however, be otherwise explained as a subtle psychological touch. Agamemnon is thinking of his own case, and wishing that he had died far from his home, which was Argos. His thoughts are running on Argos and so he congratulates Achilles on laving fallen far from Argos, where he should have said, from Achilles' point of view, Phthia. But I question whether this will be considered probable.

6. $\mathrm{Z} 224$. 
who still prefer it are entitled to say that, in the first place, it is quite conceivable that Menelaus meant to visit not merely princes who were in a relation of subjection to himself, but friendly and independent princes in northern Greece, who would liberally bestow gifts on the son of Odysseus, even as Menelaus himself bestowed them; and that, in the second place, the proposition, made for the sake of politeness, is, though it may sound preposterous, still conceivable, and that whether a delay of five days or five weeks is proposed is after all only a question of degree. With the first of these observations I quite agree, and I lave not used the consideration as to the dependence or independence of those who were to present the gifts as an argument to base my case on; but at the same time I regard it as more probable that dependent entertainers are implied. In regard to the second observation, the question is-of course-one of degree; but this does not weaken the force of $\mathrm{my}$ objection to the received interpretation. Suppose A and $B$ are staying together at $N$ ice, and $A$, one day, tells $B$ that he wishes to start for London immediately. It is quite conceivable that $B$, knowing $A$ 's business to be really important, might still say, "Very well ; but don't you think you could manage, instead of going direct by Lyons, to come with me to Milan and return by the St. Gothard?' but it is quite inconceivable that, under the circumstances, a reasonable person would propose an excursion to Algiers or Palermo.

But, notwithstanding the difficulty, ${ }^{62 i}$ we might be content to acquiesce in the accepted view, if there were any positive proof that Hellas ever did designate northern Greece. But there is, as we have seen, no such proof, and therefore the accepted view is simply unfair to the poet. The difference between the hypothesis advocated here, that Hellas meant Peloponncsian Achaia, and the current hypothesis, is that (1) the former suits the context in question and the latter does not, (2) the former rests on a certain historical probability, whereas the latter is gratuitous and improbable.-As to the view that Hellas meant the original Hellas in Thessaly, this could not with any plausibility be maintained. For why should the poet single out the little principality of Amyntor as one of the chief objects of the tour?

This conjecture as to the history of the name Hellas I should not have presumed to promulgate, if it merely rested on this one passage in the Telemachy. It is however strangely confirmed by evidence from a totally different quarter. And this confirmation will also supply us with a solution of the main problem, How Hellas and Hellenes acquired their widest signification.

$62+$ It may be saicl that the anthor of the 'lelemachy ignored, or was ignorant of, geo. graphy. The journey of Telemachus from Pylos to Sparta, by chariot and in two clays, has been iwelt on, for example, by Professor Mahafly (Greek Lit., vol. i. cal. 4). 'This was of course a poetic license. But such a liberty (or ignorance) in a swaller nutter is very difierent from the ignoring of the general geography of Grece implied in the view which I have tried to refutc. Real geography (though sometimes enroneous in detail) is one of the features of the Telemachy, in contrast with the mythical geography of tlie cliler parts of the Odyssey. 
The Greek colonization of Southern Italy and Sicily began in the latter half of the eighth century. In this movement the Achaeans of the Peloponnesus took an important and prominent part. They founded no cities in Sicily, but along the eastern shore of the promontory which at that time, and for a long time after, was called Italia-the original Italy, that is the later Bruttium, the modern Calabria,-they founded a row of cities of which the most eminent were Sybaris and Croton, followed at a later date by Metapontum, near the north point of the gulf. ${ }^{63}$ These cities soon threw off shoots across the narrow mountainous promontory to the coast of the western sea. ${ }^{6 .}$ The Achaean colonies grew and multiplied. Now this group of colonies, flanked at one extremity by Spartan Taras, at the other by Locri, came to be distinguished by the special name of $\mathrm{M} \epsilon \gamma a ́ \lambda \eta{ }^{~ ' E} \lambda \lambda a$ s, which the Romaus rondered by Magna, Graecia. ${ }^{65}$ It is perfectly clear that the name cannot have been given at a time when 'Hellas' had acquired its universal meaning. It is absurd to suppose that this group of settlements was called Great Greece, with the implication that the whole mother country was Little Greece. If indeed Sicily had been included under the appellation 'Great Greece,' such an explanation might be just conceivable. ${ }^{60}$ But it is quite out of the question to suppose that colonial arrogance would have led the towns of the south-western promontory of Italy to denominate themselves Great Greece in contrast with the whole of what we call Greece proper. Hence the name must have been given before Hellas had come to bear its Panhellenic meaning.

It need liardly be remarked that M $\epsilon \gamma a \dot{\lambda} \eta{ }^{~ ' E} \mathrm{E} \lambda \alpha \alpha^{\prime}$ s could have had no reference to the old Hellas of Amyntor. ${ }^{67}$ For the two countries had nothing to do with each other,- there is no trace of any historical connexion; and moreover, when the earliest colonies of south Italy were planted, the original Hellas, as we have already seen, cannot have been still in existence; for, if it had been, some trace of their name and place in those regions must lave been preserved, probably in connexion with the Amphictyonic league.

But if Hellas was, as I suppose, in the eighth century a name for the

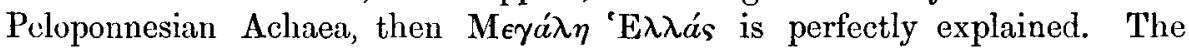
cities planted, and the territory acquired, beyond the sea by the Hellencs was called Great Hellas, as opposed to their mother country-their second

(is Aiso, Petelia, Scylacium, Caulonia.

64 Terina, Tenresa, Lans, Posidonia.

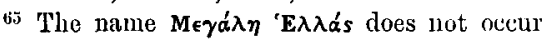
in any early extant document; but we know that it was in use in the latter half of the 6th century from Polybius, who clearly found it in his authorities. 'The passage is (ii. 39): $\kappa a \theta^{\prime}$

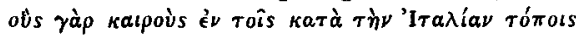

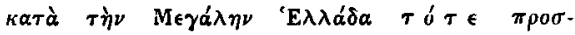

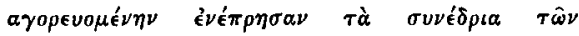
$\Pi v \theta a \gamma o \rho \in i \omega \nu$.

(66 Sce Pliny 3, 95. Complare $\Lambda$ thenieus

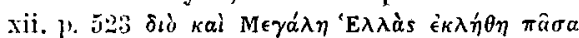

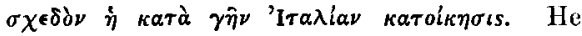
explains the name by the populousness of the colonies. His statement is interesting, for he evidently had before him an old authority, in which 'Ira入ía was nsed in its original sense, of the toe. Strabo is, of course, wrong when he includes Sicily under the name,- perhaps from some sense of the difficulty in explaining the appellation; p. $253=$ Bk vi. $1,2$.

${ }_{67} \Lambda$ suggestion of this kind was put forward by E. Meyer, Philol., N.F. 1889, 1. 2厅4. He does not repeat it in his Gesch. des Altcriuns but it met with busolt's apjoroval. 
home-the strip of land along the north coast of the Peloponnesus. That the name, originally belonging to the Hellenic or Achaean cities, should be afterwards extended to the neighbouring Greek cities, which were not of Achaean origin, on the same coast, for example to Locri and Taras, was simply inevitable, once the name 'Hellas' had won its wider meaning and the true origin of 'Great Hellas' was forgotten.

And it is just here, on the south Italian shores, that Hellenes began to acquire the Panhellenic signification, which soon came to be universally adopted. The natives of southern Italy, when the Achaean and Hellenic colonies were first planted among them, came to use the name Hollones for all men of the same race and language as the Achaean Hellenes. No cause (it may be remarked by the way) more powerfully promoted the growih of a feeling of unity among the Greeks-the consciousness of ther common race and common language-than the institution of colonization which brought them into contact with many various kinds of not-Greek peoples. The names Greek and barbarian are conjugate terms, as Thucydides pointed out; their meanings mutually depended on each other. And therefore, a priori one expects that the name 'Hellenes' should have obtained its universal sense, just because Hellenes, in the special sense, had been brought into contact with non-Greeks.

This is what happened in other cases. Among the Semites, the Greeks were known as Iavones, because the oriental nations had special contact with the 'Iáfoves $r$ Ionians on the coast of Asia Minor. ${ }^{68}$ But the name 'Greek' itself, by which the Romans designated, and we in the west still designate, the Hellenes, is a more striking instance in point. One of the earliest colonies in the west, though by no means as early as used to be supposed, ${ }^{69}$ was founded by Euboean settlers and derived its name from the Euboean town of Cyme. But along with the Euboeans were associated some colonists from the opposite mainland, belonging to the little territory of

68 'Apropos: the derivation of 'laves from the full form 'Iáfoves has puzzled philologists. It should certainly be explained as a 'Koseform.' There seems some tendency now, and it seems to me justifiable, to go back to the old view which connected the original Iavones, who gave their name to all the colonies between certain limits on the Asiatic coast, with a vestern district in the Peloponnesus. (The complication of this connexion by the further connexion with Attica seems extremely doubtful.) If so, we might conjecture that in their old home, where their name was completely forgotten, there had prevailed another hylocoristic abridgement, in which the $\iota$, but not the o, was lengthened: "Ioves, and that from them the Ionian Sea, 'Ióvıos rópos, derived its name. ia foves, with the two liypocoristica ioves and icuves, would be pretty. I take this opportunity of observing that the mention of the Ionians (Yevana) among the allies of the Hittites, in the epic of Ramses ii, has not been duly appreciated. Three inferences are possible, and any of these would be very im. portant. (1) The Ionians hal already begun to settle in Asia Minor by the end of the fourteenth century B.c. (2) The Ionians were still in the Peloponnesus, and took no part in the war, but their name was so well known that the poet included them (cf. W. Max Miiller, Asien und Europa, 370 'Diese Erwihmung besagt keineswegs dass die Ionier zu den kleinasiaten oder gar zum Hetiterreich zu rechnen sind. Der Dichter zihlt wohl alle ihm bekannten Westländer unter den "Genossen" des siegreichen Königs'). (3) Ionians used at this time to cross the seas and hire themselves out as mercenary soldiers.

69 Helbig, Des hom. Eyos, Hpendix. Busolt, Gr. Gesch, i. $2 \pm 7$. 
Graia in the neighbourhood of Oropus. The destinies of names are indeed mysterious. The Graian name, always obscure in its original place on the borders of Attica and Boeotia, was fated, through its connexion with Italian Cyme, to become the European name of the whole race, of which the Graes were among the most insignificant members. The Oscans and other Italians, who had dealings with the new men who had settled among them, selected, perhaps by some incalculable instinct of the tongue, the name of the Graians in preference to the special names of their fellow-settlers from Euboea; and the name by which they distinguished the first Greeks they knew was naturally applied to the whole race. Thus in Campania and Latium, Graci, and then with the Italian adjectival termination Gracei, was adopted as the general name for the Hellenes.

And so it was with the name Hellenes itself. 'Greek' was the name established in central Italy, because there Graes happened to have settled; 'Hellones' was the name established in the extreme south of Italy-in the original Italy-because there Hellenes happened to have settled. The same instinct which in one case led to the choice of 'Graes' in preference to 'Chalcidians' or 'Cymeans,' led in the other case to the choice of 'Hellenes' in preference to 'Achaeans.' But while the Greek name took root in the neighbourhood of a remote and isolated colony, which was probably at first little visited by other than Euboean Greeks, the Hellenic name was established within the limits of an active sphere of colonization, where rival merchants from various parts of the Greek world sought a market. Milesians and Chalcidians, Locrians and Achaeans, Megarians and Corinthians, finding themselves all called Hellenes by the Italian races, came to designate themselves as Hellenes in contrast with the barbarians. The barbarians brought home to them their own unity and also chose them a name for expressing that unity.

The name Hellas gained a corresponding extension, after a time. And when it became extended, it ceased to be used in its former limited sense, just as when the name Italia became extended over a large part of the peninsula it ceased to be used in the original and proper sense which confined it to the toe. In the east the other name, Achaea, asserted itself to the exclusion of Hellas; and while in the west the name Great Hellas survived, it was immediately forgotten why it had been so called, and was probably supposed to imply somewhat the same idea as our borrowed phrase "Greater. Britain.'

The history of the name Hellas may now be briefly summed up. It originally signified a small territory in the south of the land which in historical times was known as Thessaly, and adjoined, if it did not form part of, Phthia; and belonged to the Achatean realm which is known in the epics as the kingdom of Peleus. The record of this stage is to be found mainly in part of a very old epic poem which has been worked into the ninth Book of our Iliad. In the next stage the name has passed to the north coast of the Peloponnesus; Hellenes and Achaeans have migrated southward, owing to the Thessalian invasion. Here too Achaeans and 
Hellenes live together; and the land is associated with both names. The record of this stage is to be found in the Telemachia (8th century) in the passage which occupied our attention, and in the name Great Hellas. In the seventh century we reach the third stage, and find that 'Hellenes' has ceased to designate a special people and has come to designate all the Greeks, and the compound Panhellenes has been formed. By the end of that century judges connected with the festival of Zeus at Olympia bear

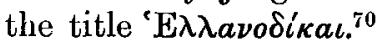

\section{J B. BuRy.}

70 Parisanias, v. 9, 4, states that in 580 two officers of this name were appointed, there having been one heretofore. This statement, if sound, gives a posterior limit for the Elean inscription in which one ex入avosikas is mentioned (Collitz, Sammlung i. no. 1152). 